\title{
Two-Dimensional Luminescent Rectangular Molecular Grids Containing Copper(I)-Olefin Bonds as Bridging Spacers
}

\author{
J ing Zhang, ${ }^{\dagger}$ Ren-Gen Xiong, ${ }^{*},+X_{\text {Xue-Tai Chen, }}^{\dagger}$ Ziling Xue, $^{\ddagger}$ \\ Shie-Ming Peng, ${ }^{\$}$ and Xiao-Zeng $\mathrm{You}^{\dagger}$ \\ Coordination Chemistry Institute, The State Key Laboratory of Coordination Chemistry, \\ Nanjing University, 210093, Nanjing, People's Republic of China, Department of Chemistry, \\ University of Tennessee, Knoxville, Tennessee 37996, and Department of Chemistry, \\ National Taiwan University, Taipei, Taiwan
}

Received J uly 25, 2001

Summary: Thereaction of $\mathrm{CuCl}$ with 4-vinyl pyridine (4VPY) under hydrothermal conditions affords a 2-D copper (I )-olefin luminescent coordination polymer, [Cu(4VPYA)Cl ]n (1), with an approximately molecular rectangular grid dimension of $10.576 \times 7.322 \AA$.

\section{Introduction}

Supramol ecular motifs containing a ol efin-copper(I) bond as bridging spacer have recently attracted much attention. ${ }^{1}$ Copper(I)-olefin complexes are known to play an important role in biochemistry and modern organic chemistry and are involved as catalytically active species or resting states in copper-catalyzed addition of carbanions to $\alpha, \beta$-unsaturated carbonyls and copper-catalyzed cyclopropanation of alkenes by $\alpha$-carbonyl diazoalkanes. ${ }^{2,3}$ Although a large number of metal-organic coordination polymer networks or cyclophanes such as squares and grids are documented in the recent literature, ${ }^{4,5}$ the functional (luminescent) molecular grid or square grid (molecular box) containing

* Corresponding author. E-mail: xyz@etra.nju.edu.cn. Fax: (+86) 253317761 or $(+86) 253314502$.

+ Nanjing University.

‡ University of Tennessee.

§ National Taiwan University.

(1) (a) Young, D. M.; Geiser, U.; Schultz, A. J .; Wang, H. H. J . Am. Chem. Soc. 1998, 120, 1331. (b) Zhang, J .; Xiong, R.-G.; Zuo, J .-L.; You, X.-Z. Chem. Commun. 2000, 1495. (c) Zhang, J .; Xiong, R.-G.; Zuo, J .L.; Che C.-M.; Y ou, X.-Z. J . Chem. Soc., Dalton. Trans. 2000, 2898. (d) Zhang, J .; Xiong, R.-G.; Chen, X.-T.; Che, C.-M.; Xue Z.-L.; You, X.-Z. Organometallics 2001, 20, 4118. (e) Engelhardt, L. M.; Healy, P. C.; Kildea, J. D.; White, A. H. Aust. J . Chem. 1989, 42, 185.

(2) (a) Hallnemo, G.; Olsson, T.; Ullenius, C. J . Organomet. Chem. 1985, 282, 133. (b) Mori, S.; Nakamura, E. Chem. E ur. J . 1999, 5, 1534. (c) Diaz-Requejo, M. M.; Nicasio, M. C.; Perez, P. J . Organometallics 1998, 17, 3051. (d) Diaz-Requejo, M. M.; Belderrain, T. R.; Nicasio, M. C.; Prieto F.; Perez, P. J . Organometallics 1999, 18, 2601. (e) Striejewske, W. S.; Conry, R. R. Chem. Commun. 1998, 555. (f) Shimazaki, Y.; Yokoyama, H.; Yamauki, O. Angew. Chem., Int. Ed. 1999, 38, 2401. (g) Diaz-Requejo, M. M.; Belderrain, T.; Perez, P. J . Chem. Commun. 2000, 1853. (h) Thompson, J. S.; Harlow, R. L. Whitney, J . F. J . Am. Chem. Soc. 1983, 105, 3522. (i) Thompson, J . S.; Whitney, J . F.J . Am. Chem. Soc. 1983, 105, 5488. (j) Thompson, J . S. Whitney, J . F. Inorg. Chem. 1984, 23, 2813. (k) Thompson, J. S. Harlow, R. L.; Swiatek, M. Inorg. Chem. 1985, 24, 110. (I) Masuda, H.; Yamamoto, N.; Taga, T.; Machida, K.; Kitagawa, S.; Munakata M. J . Organomet. Chem. 1987, 322, 121. (m) Munakata, M.; Kitagawa, S.; Kosomo, S.; Asahara, A. N. I norg. Chem. 1986, 25, 2622. (n) Doyle, G.; Eriksen, K. A.; Van Engen, D. Organometallics 1985, 4, 830. copper (I )-olefin bonds still remains, to the best of our knowledge, unknown. Successful access toluminescent molecular grids with ol efin-copper(I) bonds remains a great challenge. Inspired by the pioneering work of Hupp and other groups on luminescent molecular boxes, ${ }^{6-8}$ we have used 4-vinylpyridine (4-VPY) as bridging ligand to react with $\mathrm{CuCl}$ under hydrothermal reaction conditions to construct a novel luminescent 2-D rectangular neutral grid, $\{\mathrm{Cu}(4-\mathrm{VPY}) \mathrm{Cl}\}_{\mathrm{n}}(\mathbf{1})$, containing

(3) (a) Schaller, G. E.; Bleecker, A. B. Science 1995, 270, 1809. (b) Rodriguez, F. I.; Esch, J . J .; Hall, A. E.; Binder, B. M.; Schaller, G. E. Bleecker, A. B. Science 1999, 283, 996. (c) Ecker, J. R. Science 1995, 268, 667. (d) Straub, B. F.; Eisentrer, F.; H ofmann, P. Chem. Commun. 1999, 2507. (e) Cavallo, L.; Cucciolito, M. E.; Martino, A. D.; Giordano, F.; Orabona I.; Vitagliano, A. Chem. Eur. J. 2000, 6, 1127, and references therein.

(4) (a) Batten, S. R.; Robson, R. Angew. Chem., Int. Ed. 1998, 37, 1460. (b) Yaghi, O. M.; Li, H.; Davis, C.; Richardson, D.; Groy, T. L. Acc. Chem. Res. 1998, 31, 474. (c) J aniak, C. Angew. Chem., Int. Ed. Engl. 1997, 36, 1431. (d) Zaworotko, M. J. Chem. Soc. Rev. 1994, 23 283. (e) Carlucci, L.; Ciani, G.; Proserpio, D. M.; Sironi, A. Angew. Chem., Int. Ed. Engl. 1995, 34, 1895. (f) Hirsch, K. A.; Wilson, S. R.; Moore, J. S. Chem. Commun. 1998, 13. (g) Fujita, M. Chem. Soc. Rev. 1998, 27, 417.

(5) (a) Leininger, S.; Olenyuk, B.; Stang, P.J . Chem. Rev. 2000, 100, 853. (b) Lu, J.; Yu, C.; Niu, T.; Paliwala, T.; Grisci, G.; Somosa, F.; J acobson, A. J . Inorg. Chem. 1998, 37, 4637. (c) MacGillivray, L. R.; Atwood, J. L. Angew. Chem., Int. Ed. 1999, 38, 1081. (d) J ones, C. J. Chem. Soc. Rev. 1998, 27, 289. (e) Hagrman, P. J .; Hagrman, D. Zubieta, J. Angew. Chem., Int. Ed. 1999, 38, 2638. (f) Lin, W.; Evans, O. R.; Xiong, R.-G.; Wang, Z. J . Am. Chem. Soc. 1998, 120, 13272. (g) Cotton, F. A.; Daniels, L. M.; Lin, C.; Morillo, C. A. J . Am. Chem. Soc. 1999, 121, 4538. (h) Huang, S. D.; Xiong, R.-G. Polyhedron 1997, 16, 3929.

(6) (a) Keefe, M. H.; Benkstein, K. D.; Hupp, J. T. Coord. Chem Rev. 2000, 205, 201. (b) Benkstein, K. D.; Hupp, J . T.; Stern C. L. J . Am. Chem. Soc. 1998, 120, 12982. (c) Benkstein, K. D.; Hupp, J. T.; Stern C. L. Angew. Chem., Int. Ed. 2000, 39, 2891. (d) Slone, R. V.; Hupp, J . T. Inorg. Chem. 1997, 36, 5422, and references therein. (e) Slone, R. V.; Benkstein, K. D.; Belanger, S.; Hupp, J . T.; Guzei, I. A.; Rheingold, A. L. Coord. Chem. Rev. 1998, 171, 221. (f) Benkstein, K. D.; Hupp, J. T.; Stern C. L. Inorg. Chem. 1998, 37, 5404.

(7) (a) Sun, S. S.; Lees, A. J . J . Am. Chem. Soc. 2000, 122, 8956. (b) Sun, S. S.; Lees, A. J . Organometallics 2001, 20, 2353. (c) Sun, S. S.; Lees, A. J . Chem. Commun. 2001, 103. (d) Sun, S. S.; Lees, A. J . Chem. Commun. 2000, 1687. (e) Sun, S. S.; Lees, A. J . Inorg. Chem. 1999 38, 4181. (f) Sun, S. S.; Silva, A. S.; Brinn, I. M. Lees, A. J . Inorg. Chem. 2000, 39, 1344

(8) (a) Xiong, R.-G.; Zuo, J .-L.; You, X.-Z.; Fun, H.-K.; Raj, S. S. S Organometallics 2000, 19, 4183. (b) Rajendran, T.; Manimaran, B.; Lee, F.-Y.; Lee, G.-H.; Peng, S.-M.; Wang, C. M.; Lu, K. L. I norg. Chem. 2000, 39, 2016. (c) Chen, Z.-F.; Xiong, R.-G.; Zhang, J .; Chen, X.-T.; Xue, Z.; You, X.-Z. Inorg. Chem. 2001, 40, 4075. 


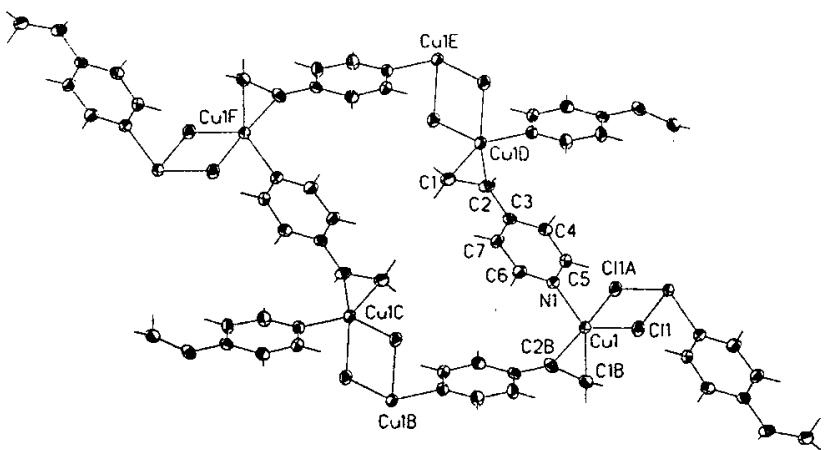

Figure 1. Rectangular unit representation of $\{\mathrm{Cu}(4-\mathrm{VPY})-$ $\mathrm{Cl}_{\mathrm{n}}$ (1). The thermal ellipsoids are drawn at 30\% probability level. Selected bond lengths $(\AA)$ and angles (deg): $\mathrm{Cu}(1)-\mathrm{N} 12.006(2), \mathrm{Cu}(1)-\mathrm{C}(1 \mathrm{~B}) 2.025(3), \mathrm{Cu}(1)-\mathrm{C}(2 \mathrm{~B})$ 2.064(3), $\mathrm{Cu}(1)-\mathrm{Cl}(1)$ 2.2599(8), $\mathrm{Cu}(1)-\mathrm{Cl}(1 \mathrm{~A})$ 2.6751(8), $\mathrm{C}(1 \mathrm{~B})-\mathrm{C}(2 \mathrm{~B})$ 1.364(4); C(1B)-Cu(1)-Cu(2B) 38.97(1), N(1)$\mathrm{Cu}(1)-\mathrm{C}(1 \mathrm{~B})$ 148.16(11), N(1)-Cu(1)-C(2B) 110.78(10), $\mathrm{N}(1)-\mathrm{Cu}(1)-\mathrm{Cl}(1)$ 105.56(7), $\mathrm{N}(1)-\mathrm{Cu}(1)-\mathrm{Cl}(1 \mathrm{~A})$ 94.66(7), $\mathrm{C}(1 \mathrm{~B})-\mathrm{Cu}(1)-\mathrm{Cl}(1) \quad 100.88(10), \quad \mathrm{C}(2 \mathrm{~B})-\mathrm{Cu}(1)-\mathrm{Cl}(1 \mathrm{~A})$ 138.78(9), C(1B)-Cu(1)-Cl(1A) 99.01(10), C(2B)-Cu(1)$\mathrm{Cl}(1 \mathrm{~A})$ 97.9(8), $\mathrm{Cl}(1)-\mathrm{Cu}(1)-\mathrm{Cl}(1 \mathrm{~A})$ 97.87(3), $\mathrm{Cu}(1)-\mathrm{Cl}(1 \mathrm{~A})-$ $\mathrm{Cu}(1 \mathrm{G})$ 82.13(3).

\section{Scheme 1}

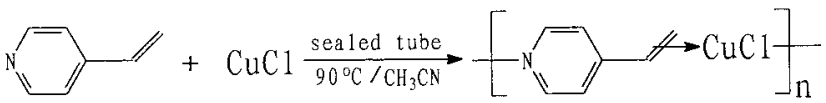

\section{1}

a $\eta^{2}$-copper (I)-olefin bond as connecting spacer. Herein we report its synthesis, crystal structure, and luminescent property.

\section{Results and Discussion}

1 was synthesized under hydrothermal conditions through the reaction between $\mathrm{CuCl}$ and 4-VPY (Scheme 1). 1 possesses high thermal stability, as shown in its thermogravimetric analysis (TGA). The TGA of the polycrystalline 1 showed no weight loss between ca. 50 and $160{ }^{\circ} \mathrm{C}$, while an endothermal reaction occurred at $160{ }^{\circ} \mathrm{C}$ with a weight loss of ca. $4.1 \%$, probably corresponding to the removal of the absorbed 0.5 water $(4.409 \%)$. The framework was stable up to $350{ }^{\circ} \mathrm{C}$ and collapsed beyond that temperature. The EPR spectrum of a single crystal of $\mathbf{1}$ is silent, indicating that the status of the $\mathrm{Cu}$ atom in $\mathbf{1}$ is $\mathrm{Cu}(\mathrm{I})$.

The X-ray crystal analysis of complex 1 (Figure 1) revealed that the $\mathrm{Cu}(\mathrm{I})$ ion in $\mathbf{1}$ is coordinated in a distorted tetrahedral geometry, which is defined by two chloride atoms and one nitrogen atom and the $\mathrm{C}-\mathrm{C}$ moiety of the olefin. Thus, 4-VPY acts as bidentate spacer to link two $\mathrm{Cu}$ atoms, while the $\mathrm{Cl}$ atom also bridges two $\mathrm{Cu}$ atoms, leading to the formation of a 2-D framework, as shown in Figure 2. The framework belongs to a wall-brick net type, as shown in Figure 3. Each rectangular net in $\mathbf{1}$ has an approximate dimension of $10.576 \times 7.322 \AA$, as defined by Cu1-Cu1B$\mathrm{Cu} 1 \mathrm{~F}-\mathrm{Cu}$ IE . It is interesting to note that the two longer sides of each rectangle contain the $\mathrm{Cu}_{2} \mathrm{Cl}_{2}$ dimer moiety to extend this side, and the distance between CulB and CulC is about $3.254 \AA$. This suggests that the cavity can intercalate or include a guest molecule. The pack-

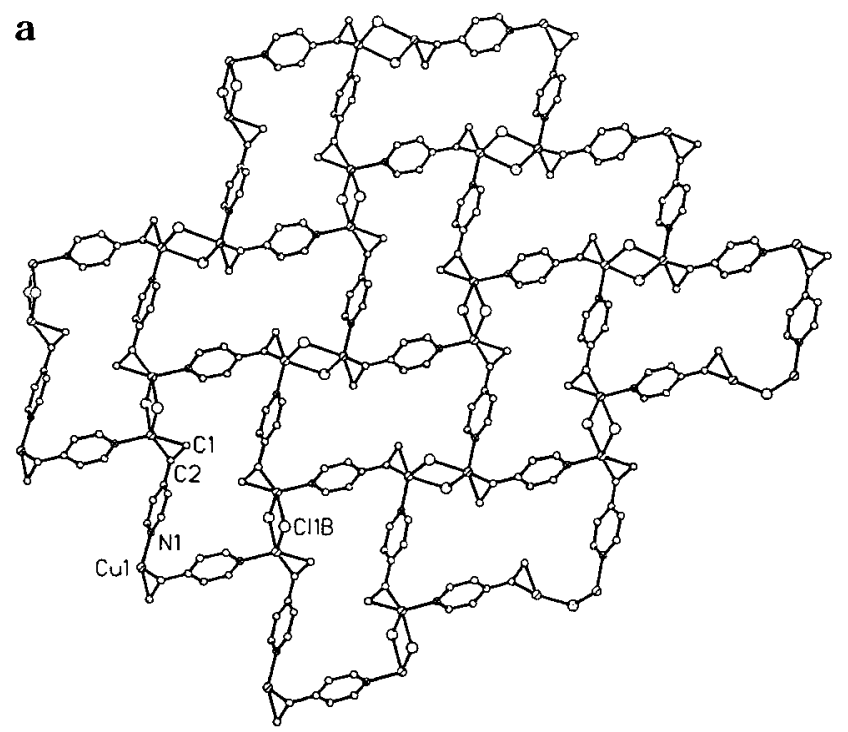

b

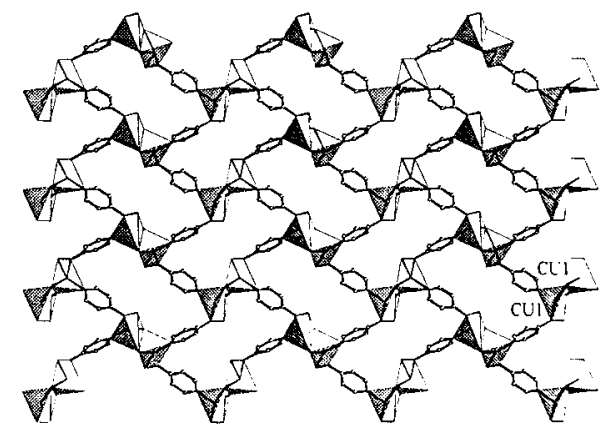

Figure 2. (a) 2-D rectangular grid representation of $\{\mathrm{Cu}(4-$ $\mathrm{VPY}) \mathrm{Cl}\}_{\mathrm{n}}$ (1); (b) 2-D rectangular grid highlighting the $\mathrm{Cu}$ atom pseudo-trigonal pyramid.

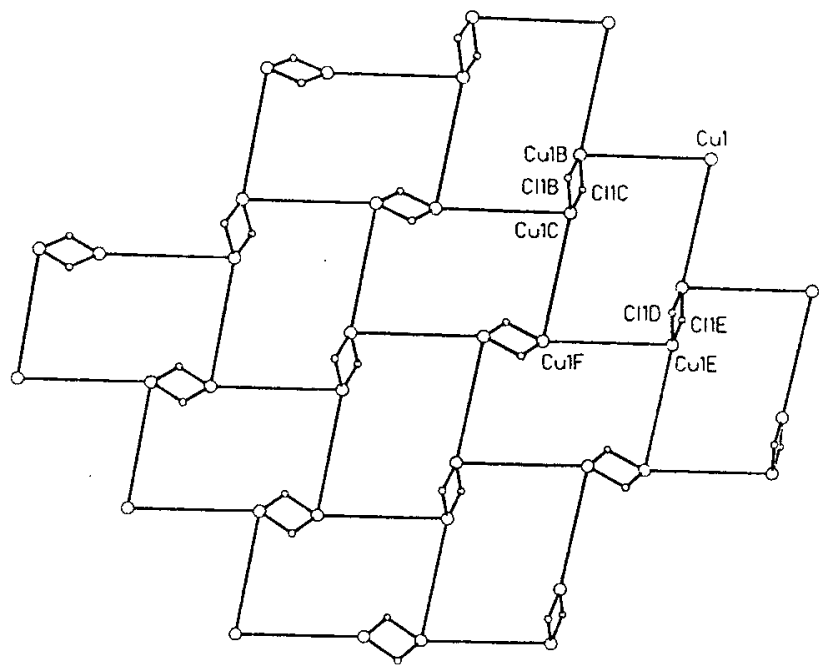

Figure 3. Simplified brick-wall 2-D framework view of $\{\mathrm{Cu}(4-\mathrm{VPY}) \mathrm{Cl}\}_{\mathrm{n}}$ (1) in which long straight lines and open circles with increasing sizes represent 4-VPY, $\mathrm{Cl}$, and $\mathrm{Cu}$ atoms, respectively.

ing view (F igure 4) shows that the two adjacent layers are in a staggered arrangement and adopt an AB type layer.

Worthy of note are $\left[\mathrm{C}_{8} \mathrm{H}_{8} \mathrm{CuCl}\right]$ and $\left(\mathrm{C}_{7} \mathrm{H}_{8} \mathrm{CuCl}\right)_{4}$ $\left(\mathrm{C}_{8} \mathrm{H}_{8}=\right.$ cyclooctatetraene and $\mathrm{C}_{7} \mathrm{H}_{8}=$ bicyclo[2.2.1]hepta- $2 \pi, 5$-diene) reported by Doyle and co-workers, ${ }^{9}$ in which the $\mathrm{Cu}$ atom was bridged by only one $\mathrm{Cl}$ atom, 


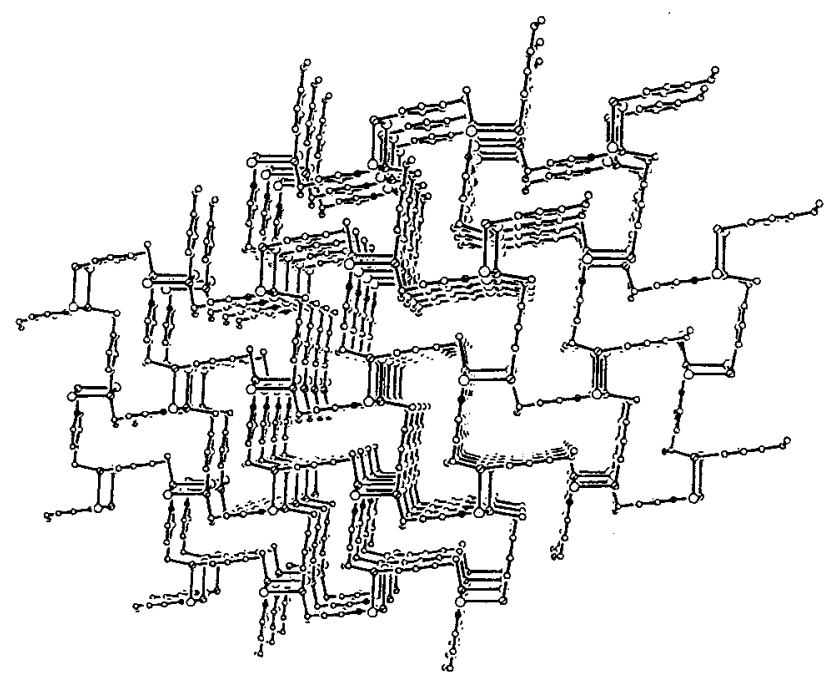

Figure 4. Packing view of $\{\mathrm{Cu}(4-\mathrm{VPY}) \mathrm{Cl}\}_{\mathrm{n}}(\mathbf{1})$ along the a-axis.

and the former is a one-dimensional chain, while the latter is a tetramer. Recently some copper (I)-ol efin complexes containing $\mathrm{Cl}$ or $\mathrm{Br}$ atoms as counterions have been also documented in the literature. Most of these complexes are monomeric, and a few are an infinite chain. ${ }^{10}$ However, it is worthy of noting that these $\pi$-complexes with $\mathrm{CuCl}$ are very unstable and decompose easily at room temperature even if they also display polymeric structures. ${ }^{10}$

The $\mathrm{C}-\mathrm{C}$ bond distance (1.364(4) $\AA$ ) for the coordinated olefin $\mathbf{1}$ is slightly longer than that found in $\left[\mathrm{Cu}_{2} \mathrm{Cl}_{2}\left(\mathrm{C}_{5} \mathrm{H}_{8}\right)\right]\left(\mathrm{C}_{5} \mathrm{H}_{8}=\right.$ 2-methyl butadiene) (1.358(7) $\AA)^{10}$ but slightly shorter than those found in $[\mathrm{CuCl}-$ $\left.\left(\mathrm{C}_{5} \mathrm{H}_{8} \mathrm{O}\right)\right]\left(\mathrm{C}_{5} \mathrm{H}_{8} \mathrm{O}=1\right.$-penten-3-one) $(1.383(8) \AA)^{10 a}$ and $\left[\mathrm{CuCl}\left(\mathrm{C}_{4} \mathrm{H}_{6} \mathrm{O}_{2}\right)\right]\left(\mathrm{C}_{4} \mathrm{H}_{6} \mathrm{O}_{2}=\right.$ methyl propenoate) (1.370(8) $\AA$ ). ${ }^{10 \mathrm{~b}}$ It is interesting to note that the $\mathrm{C}-\mathrm{C}$ bond lengths of the coordinated olefin in the two copper $(I) \pi$-complexes $\mathrm{Cu}_{4} \mathrm{Cl}_{4} \mathrm{~L}(1.33(2) \AA)$ and $\mathrm{Cu}_{4} \mathrm{Br}_{4} \mathrm{~L}$ (1.34(2) $\AA$ ) (L = $\mathrm{C}_{7} \mathrm{H}_{8}, 1,4$-pentadiene) containing a $\mathrm{Cu}_{4} \mathrm{X}_{4}$ cubane core are slightly shorter than that of $\mathbf{1}$, but the $\mathrm{Cu}-\mathrm{C}$ bond distances in $\mathrm{Cu}_{4} \mathrm{Cl}_{4} \mathrm{~L}(2.10(1)-2.06(1) \AA)$ and $\mathrm{Cu}_{4} \mathrm{Br}_{4} \mathrm{~L}$ $(2.05(1)-2.10(1) \AA)$ are al most comparable to that in $\mathbf{1}$ $(2.025(3)-2.064(3) \AA) .{ }^{10 e}$ In addition, the $\mathrm{Cu}-\mathrm{Cl}$ bond lengths in the $\mathrm{Cu}_{2} \mathrm{Cl}_{2}$ dimer of $\mathbf{1}$ are not equal to each other; thus the distance between $\mathrm{Cu}$ and $\mathrm{Cu}$ is slightly too long for a $\mathrm{Cu}-\mathrm{Cu}$ interaction in $\mathbf{1}$.

The diffuse reflectance UV-vis spectrum of $\mathbf{1}$ shows a high-energy band at ca. $244 \mathrm{~nm}$ and a low-energy band at ca. $369 \mathrm{~nm}$. The former may be assigned to the intraligand transition of the ligand 4-VPY, as 4-VPY as a free ligand in solution shows a band at ca. $250 \mathrm{~nm}$, while the low-energy band could be assigned to a metalto-ligand charge transfer (MLCT). ${ }^{11,12}$ However, the metal center $\mathrm{d}$ to $\mathrm{s}$ orbital transition could not be ruled out. ${ }^{12}$ The luminescent spectrum of $\mathbf{1}$ in the solid state at room temperature is shown in Figure 5, with a

(9) (a) Baenziger, N. C.; Richard, G. F.; Doyle, J . R. Inorg. Chem. 1964, 3, 1529. (b) Baenziger, N. C.; Haight, H. L.; Doyle, J . R. Inorg. Chem. 1964, 3, 1535.

(10) (a) Hakansson, M.; J agner, S. J . Organomet. Chem. 1987, 336, 279. (b) Hakansson, M.; J agner, S. J . Organomet. Chem. 1989, 361 269. (c) Hakansson, M.; J agner, S. Organometallics 1991, 10, 1317. (d) Hakansson, M.; J agner, S. J . Organomet. Chem. 1990, 397, 383. (e) Hakansson, M.; J agner, S.; Clot, E.; Eisenstein, O. Inorg. Chem. 1992, 31, 5389. (f) Hakansson, M.; Wettstrom, K.; J agner, S. J . Organomet. Chem. 1991, 421, 347.

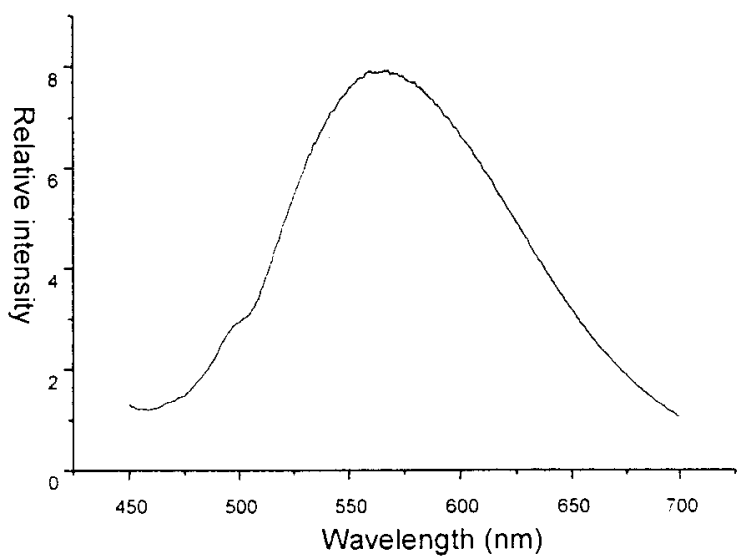

Figure 5. Luminescent spectrum of $\{\mathrm{Cu}(4-\mathrm{VPY}) \mathrm{Cl}\}_{\mathrm{n}}(\mathbf{1})$ in the solid state at room temperature.

maximum at ca. $580 \mathrm{~nm}\left(\lambda_{\mathrm{ex}}=240 \mathrm{~nm}\right)$ that is similar to those found in $\mathrm{Cu}_{4} \mathrm{l}_{4}$ (pyridine $)_{4}\left(\lambda_{\operatorname{emax}}=580 \mathrm{~nm}\right)$, $\left[\mathrm{Cu}\left(3,4^{\prime} \text {-bipyridine }\right)(\mathrm{Br})\right]_{\mathrm{n}}\left(\lambda_{\operatorname{emax}}=580 \mathrm{~nm}\right),{ }^{11,12}$ and $[\mathrm{Cu}(3-\mathrm{PYA})]_{\mathrm{n}}$ as well as $\left\{[(2-\mathrm{PYA}) \mathrm{Cu}(\mathrm{I})] \cdot\left(\mathrm{H}_{2} \mathrm{O}\right)\right\}_{n}\left(\lambda_{\mathrm{emax}}\right.$ $=580 \mathrm{~nm}, \mathrm{PYA}=$ acrylate). ${ }^{1}$ Thus, the emission at 580 $\mathrm{nm}$ in $\mathbf{1}$ can be tentatively assigned to MLCT since the fluorescent emission of the free ligand is observed at about $320 \mathrm{~nm}$. In addition, the shorter luminescent lifetime of $\mathbf{1}$ (ca. $\tau=1.02 \mathrm{~ns}$ ) in the solid state suggests its emission should be fluorescent emission. Interestingly, the luminescence of $\mathbf{1}$ can be quenched in an atmosphere of $\mathrm{CO}$ (carbon monoxide), probably suggesting that $\mathbf{1}$ reacts with $\mathrm{CO}$ to give an unstable intermediate, $\mathrm{Cu}(\mathrm{CO}) \mathrm{Cl}(4-\mathrm{VPY})$ (2). ${ }^{2 e, f, 10 f}$ However, the intermediate can be converted into $\mathbf{1}$ (and the luminescence can be recovered) after heating since $\mathrm{CO}$ is very labile and easily lost. ${ }^{13}$ Thus, the luminescent emission of $\mathbf{1}$ makes it a good candidate for sensing applications on the basis of recognition and inclusion of appropriate guest molecules.

\section{Experimental Section}

Preparation of 1. CuCl $(1 \mathrm{mmol})$ and 4-VPY $(2 \mathrm{mmol})$ were placed in a thick Pyrex tube (ca. $20 \mathrm{~cm}$ in length). After addition of $2.0 \mathrm{~mL}$ of $\mathrm{CH}_{3} \mathrm{CN}$, the tube was frozen with liquid $\mathrm{N}_{2}$, evacuated under vacuum, and sealed with a torch. The tube was heated at $90{ }^{\circ} \mathrm{C}$ for 2 days to give yellow block crystals (pure phase) in $55 \%$ yield based on $\mathrm{CuCl}$. Anal. Found: C, 41.24; H, 3.56; N, 6.45. Calcd: C, 41.15; H, 3.43; $\mathrm{N}, 6.86 . \mathrm{IR}\left(\mathrm{KBr}, \mathrm{cm}^{-1}\right)$ : 3081(w), 1608(s), 1559(w), 1523(m), 1485(w), 1423(m), 1400(w), 1323(w), 1258(m), 1216(m), 1106(w), 1064(m), 1014(m), 944(w), 915(w) 837(s), 799(m), 753(w), 684(w), 567(m), 523(m). CP-MAS ${ }^{13} \mathrm{C}$ NMR (ppm): 150.5, $147.4,124.8,118.5,102.6$, and 90.3 .

(11) (a) Fun, H.-K.; Raj, S. S. S.; Xiong, R.-G.; Zuo, J .-L.; Yu, Z.; Zhu, X.-L.; You, X.-Z.j' Chem. Soc., Dalton Trans. 1999, 1711.' (b) Kyle, K. R.; Ryu, C. K.; DiBenedetto, J. A.; Ford, P. C. J . Am. Chem. Soc. 1991, 113, 2954. (c) Henary, M.; Wootton, J . L.; Khan, S. I .; Zink, J . I. Inorg. Chem. 1997, 36, 796. (d) Miller, M. T.; Gantzel, P. K.; Karpishin, T. B. J . Am. Chem. Soc. 1999, 121, 4292.

(12) (a) Yam, V. W.-W.; Lo, K. K.-W. Chem. Soc. Rev. 1999, 28, 323 and references therein. (b) Cunningham, C. T.; Cunningham, K. L. H.; Michalec, J . F.; McMillin, D. R. Inorg. Chem. 1999, 38, 4388. (c) McMillin, D. R.; McNett, K. M. Chem. Rev. 1998, 98, 1201. (d) Ford, P. C.; Cariati, E.; Bourassa, J. Chem. Rev. 1999, 99, 3625, and references therein. (e) Harvey, P. D.; Drouin, M.; Zhang, T. Inorg. Chem. 1997, 36, 4998.

(13) (a) Hakansson, M.; J agner, S. I norg. Chem. 1990, 29, 5241. (b) Hathaway, B. J . In ComprehensiveCoordination Chemistry; Wilkinson, G., Ed.; Pergamon: New York, 1987; Vol. 5, p 533. (c) Pasquali, M.; Floriani, C.; Gaetani-Manfredotti, A. J . Chem. Soc., Chem. Commun. 1978, 921. 
X-ray Crystallographic Determination of 1 . Crystal data for 1: $\mathrm{C}_{7} \mathrm{H}_{7} \mathrm{ClCuN}, \mathrm{M}_{\mathrm{r}}=204.13$, monoclinic, space group, $P 21 / c, a=7.9377(11) \AA, b=9.4600$ (12) $\AA, c=10.7491(12) \AA$, $\alpha=90.00^{\circ}, \beta=109.494(11)^{\circ}, \gamma=90.00^{\circ}, V=760.89(17) \AA^{3}$, $\mathrm{Z}=4, \mathrm{~T}=293(2) \mathrm{K}, \rho_{\text {cad }}=1.782 \mathrm{~g} \cdot \mathrm{cm}^{-3}$. Mo K $\alpha$ radiation $(\lambda=0.71073 \AA), \mu=3.134 \mathrm{~mm}^{-1}, \mathrm{R} 1=0.0282, \mathrm{wR} 2=0.0664$ for 1313 observed reflections from 1737 independent reflections, GOF $=1.021$.

Acknowledgment. This work was supported by The Major State Basic Research Development Program (Grant N o. G2000077500), the National Natural Science Foundation of China, and National Science F oundation of the U.S.A. (CHE-9904338) as well as The Distinguished Overseas Young F und from NSFC (No. 20028101). We are very grateful to the referees for their excellent suggestions.

Supporting Information Available: Crystallographic $\mathrm{CIF}$ (excluding structure factors) and tables of atomic coordinates, thermal parameters, and bond distances and angles for $\mathbf{1}$ as well as the preparation of $\mathbf{2}$. This material is available free of charge via the Internet at http://pubs.acs.org.

OM010665 